\title{
An analysis of YouTube videos on female genital mutilation as a global issue
}

\author{
Küresel bir sorun olarak kadın sünneti üzerine YouTube videolarının bir analizi
}

\section{Murat Demir', Veli Avcl$^{2}$}

1 Van Yüzüncü Yıl University, Medical Faculty, Department of Urology, Van, Turkey

2 Van Yüzüncü Yıl University, Medical Faculty, Department of Pediatric Surgery, Van, Turkey

Submitted (Gelis tarihi): 2021-09-06 Accepted (Kabul tarihi): 2021-11-30

\section{Correspondence / Yazıșma} Murat Demir

Van Yüzüncü Yıl University, Department of Urology, Faculty of Medicine 65080-Van / Turkey Email: urologmurat72@gmail.com Tel: +90 43222517 01-05

Fax: +904322361054

\section{ORCID}

M.D. 0000-0001-5029-8800 V.A. $\quad 0000-0003-2856-3449$

\section{cc) (1) \$}

This work is licensed under a Creative Commons Attribution-NonCommercial 4.0 International License.

\section{Özet}

Amaç: Kadın sünneti, tüm dünyada yaygın olarak uygulanan, tıbbi olmayan nedenlerle kadın genital organının çıkarılmasıdır. Kadın sünneti genellikle kapalı toplumlarda uygulandığından bilim dünyası için karanlık bir konudur. Bu çalışmada kadın sünnetinin önlenmesinde YouTube videolarının rolünü değerlendirmeyi amaçladık.

Gereç ve Yöntemler: Bu kesitsel çalıșmada YouTube.com web sayfasında 1 Mayıs 2021 tarihinde "female genital mutilation" ve "female circumcision" anahtar kelimeleri kullanılarak net önbellek ve son güncellemeler içeren bir web tarayıcısında internet araması yapılmıştır. Arama sonuçları, yükleyicilerin demografik özellikleri, videoların kalitesi ve güvenilirliği açısından değerlendirildi.

Bulgular: Videoların çoğu kadınlar tarafından paylaşıldı. Kadınların ve sağlık çalışanlarının paylaştı̆̆ı videolar, erkekler ve din görevlileri tarafından yüklenen videolara göre daha kaliteli ve daha güvenilirdi.

Sonuç: YouTube.com videoları kadın sünnetinin önlenmesi için faydalı olabilir ancak özellikle sağlık çalışanları tarafından bu konuya daha fazla dikkat edilmeli ve daha güvenilir ve daha kaliteli videolar paylaşılmalıdır.

Anahtar Kelimeler: Sirkümsizyon, kadın, genitalya.
Abstract

Objective: Female genital mutilation is the removal of female genital organs for non-medical reasons, which is widely practiced worldwide. Female genital mutilation is a dark subject for the scientific world since it is often practiced in closed societies. In this study, we aimed to evaluate the role of YouTube videos in the prevention of female genital mutilation.

Material and Methods: In this cross-sectional study, an internet search was conducted on YouTube.com on May 1, 2021, using the keywords «female genital mutilation» and «female circumcision» on a web browser with a clear cache and latest updates. Search results were evaluated in terms of the demographic characteristics of uploaders and the quality and reliability of the videos.

Results: Most of the videos were shared by women. The videos shared by women and healthcare professionals were higher quality and more reliable compared to videos uploaded by men and religious personnel.

Conclusion: YouTube.com videos may be beneficial for the prevention of female genital mutilation, but more attention should be paid to this issue, particularly by healthcare professionals, and more reliable videos with the higher quality should be shared.

Keywords: Circumcision, female, genitalia.

Cite As: Demir M, Avcı V. An analysis of YouTube videos on female genital mutilation as a global issue. New J Urol. 2022; 17(1):31-37. D0I: 10.33719/yud.2022;17-1-991862

The study was conducted retrospectively. All research was performed in accordance with relevant guidelines/regulations. 


\section{INTRODUCTION}

Female genital mutilation (FGM), also known as female circumcision, is the partial or complete removal of female genital organs for non-medical reasons (1). This method is mostly applied for sociocultural and religious reasons and is widely performed in many countries globally, though considered infrequent. Although it is more common in West African countries, it is also administered in 28 other African countries and several Middle and Far Eastern countries. It is estimated that there are 115-130 million women with FGM globally and that around 3 million girls or women will be exposed to it every year (2-4). For these reasons, FGM can be accepted as a global problem.

In countries where FGM is implemented, the lack of governmental efforts to prevent FGM makes mass media, particularly social media, an important public education tool (5). Of these, YouTube.com is a popular social media platform and the world's largest video-sharing platform, with millions of subscribers and billions of views every day. Therefore, YouTube.com has a substantial social impact (6). A previous study examining YouTube.com videos on early childhood sexual abuse concluded that the videos were useful in preventing abuse (7).

In this study, we aimed to investigate whether YouTube.com videos about FGM could be useful for preventing FGM. To our knowledge, this is the first study in the literature to examine YouTube.com videos about FGM.

\section{MATERIAL AND METHODS}

\section{Study Design}

In this cross-sectional study, an internet search was conducted on YouTube.com on May 1, 2021, using the keywords "female genital mutilation" and "female circumcision" by two independent physicians, including one urologist and one pediatric surgeon (MD, VA, respectively). The search was conducted using a web browser with a clear cache and the latest updates. Search results were listed according to their relevance, and then the Uniform Resource Locator (URL) of the first 200 videos were recorded. Videos that were non-English, silent, and did not share any relevant information were excluded from the study.
The interaction level of the 156 videos' likes, dislikes, comments, views, and total durations was recorded for assessment. Subsequently, both physicians evaluated the videos separately in terms of content. The sources of the videos were recorded as news agencies, individual users, religious personnel, and healthcare provider, and the target audiences were recorded as healthcare professionals and the general public. The videos were evaluated in terms of quality and reliability according to the Global Quality Scale (GQS) and the DISCERN instrument. Interrater reliability was tested using the Kappa statistic. All discussions were continued until a consensus position was reached for all videos.

\section{Global Quality Scale and DISCERN}

Our study used the Global Quality Scale and Brief DISCERN questionnaires (Appendix). Global Quality Scale is a scale developed by Bernard et al. for measuring the utility, flow, and quality of videos and is widely preferred by patients and healthcare professionals due to its ease of use (8).

DISCERN is a brief online questionnaire providing internet users with a valid, impartial, and reliable way of assessing the quality of consumer health information. The questionnaire consists of 16 questions (graded 1-5). The DISCERN score has been shown compatible with the quality of health information (9-11). The Brief DISCERN, which consists of 5 questions, was developed at a later period, and its results were found to be highly compatible with those of the original DISCERN $(9,12)$

\section{Statistical Analysis}

Data were analyzed using SPSS for Windows version 21.0 (Armonk, NY: IBM Corp.). Continuous variables were expressed as mean, standard deviation (SD), and minimum-maximum values. Categorical variables were expressed as frequencies (n) and percentages (\%). Group means were compared using the One-Way ANOVA test for continuous variables, followed by Duncan's Multiple Range Test (DMRT). Correlations were determined using Pearson's Correlation Coefficient. Relationships between categorical variables were assessed using the Chi-square test. A p-value of $<0.05$ was considered significant. 


\section{Appendix:}

GQS and Brief DISCERN Instrument

\begin{tabular}{|c|c|}
\hline \multicolumn{2}{|r|}{ Global Quality Scale } \\
\hline 1 & Poor quality, poor flow of the site, most information missing, not at all useful for patients \\
\hline 2 & $\begin{array}{l}\text { Generally poor quality and poor flow, some information listed but many important topics missing, of very limited } \\
\text { use to patients }\end{array}$ \\
\hline 3 & $\begin{array}{l}\text { Moderate quality, suboptimal flow, some important information is adequately discussed but others poorly } \\
\text { discussed, somewhat useful for patients }\end{array}$ \\
\hline 4 & $\begin{array}{l}\text { Good quality and generally good flow, most of the relevant information is listed, but some topics not covered, } \\
\text { useful for patients }\end{array}$ \\
\hline 5 & Excellent quality and excellent flow, very useful for patients \\
\hline \multicolumn{2}{|r|}{ Brief DISCERN Instrument } \\
\hline 1 & Are the explanations given in the video clear and understandable? \\
\hline 2 & Are useful reference sources given? \\
\hline 3 & Is the information in the video balanced and neutral? \\
\hline 4 & Are additional sources of information given from which the viewer can benefit? \\
\hline 5 & Does the video evaluate areas that are controversial or uncertain? \\
\hline \multicolumn{2}{|r|}{ Brief DISCERN Scoring } \\
\hline $4-5$ & Good quality, involving highly useful information \\
\hline 3 & Moderate quality, involving partially useful information \\
\hline $1-2$ & Poor quality, involving little or no useful information \\
\hline
\end{tabular}

\section{RESULTS}

The results indicated that most of the 156 videos were uploaded by women $(\mathrm{n}=129 ; 82.6 \%)$. Of these, 130 (83.3\%) videos were defending FGM, while $26(16.6 \%)$ of them were against FGM, of which 20 (74.1\%) videos were uploaded by men and $6(4.7 \%)$ videos were uploaded by women $(\mathrm{p}<0.001)$. News agencies were the most common sources of the videos $(n=64)$, followed by individual users $(n=63)$, religious personnel $(n=20)$, and healthcare personnel $(n=9)$. All the videos uploaded by news agencies and healthcare personnel were against FGM, while 9 (14.3\%) videos uploaded by individuals and 17 (85\%) videos uploaded by religious personnel defended FGM $(\mathrm{p}<0.001)$.

As for the audience, all the videos addressed the general public. The average number of likes was 2,153.9, the average number of dislikes was 19.2, the average number of comments was 2,266.5, the mean duration of the videos was 580.3 seconds, the meantime from the upload date was 70.2 months, and the mean number of views was $170,196.6$. In terms of duration, the videos uploaded by religious personnel were significantly longer compared to other videos $(\mathrm{p}=0.03)$, while no significant difference was found among the videos uploaded by other sources (Table 1).

According to quality and reliability, both GQS and DISCERN scores were significantly higher in the videos presented by females compared to men ( $\mathrm{p} \leq 0.001)$, in the videos uploaded by healthcare professionals compared to other sources $(p \leq 0.001)$, and in the videos against FGM compared to the videos defending FGM $(\mathrm{p} \leq 0.001)$ (Table 2,3). The kappa coefficient for interrater reliability was 0.85 . 
Table 1. Characteristics of the videos according to their uploaders

\begin{tabular}{|c|c|c|c|c|c|}
\hline Parameter & News agency & Individual users & $\begin{array}{l}\text { Religious } \\
\text { personnel }\end{array}$ & $\begin{array}{l}\text { Healthcare } \\
\text { professional }\end{array}$ & $\mathbf{p}$ \\
\hline Likes (n) & 2182.53 & 1900.60 & 189.50 & 8089.00 & 0.26 \\
\hline Dislikes (n) & 188.83 & 136.08 & 45.05 & 191.11 & 0.45 \\
\hline Comments (n) & 5229.19 & 263.94 & 39.95 & 165.89 & 0.67 \\
\hline $\begin{array}{l}\text { Duration of } \\
\text { video (sec) }\end{array}$ & 596.50 & 541.30 & 541.30 & 646.65 & 0.92 \\
\hline Views (n) & 269658.19 & 122790.78 & 17317.90 & 134485.56 & 0.19 \\
\hline $\begin{array}{l}\text { Time from upload } \\
\text { date (months) }\end{array}$ & 71.3 & 61.02 & 90.8 & 81.8 & 0.03 \\
\hline
\end{tabular}

(In terms of duration, the videos uploaded by religious personnel were significantly longer compared to other videos ( $p=0.03$ ), while no significant difference was found among the videos uploaded by other sources) (One-Way ANOVA)

Table 2. DISCERN Scores

\begin{tabular}{|c|c|c|c|c|c|c|c|c|}
\hline & & 1 & 2 & 3 & 4 & 5 & Total & $\mathbf{p}$ \\
\hline \multirow{2}{*}{ Gender } & Male & 20 & 7 & 0 & 0 & 0 & 27 & \multirow{2}{*}{$<0.001$} \\
\hline & Female & 7 & 92 & 13 & 13 & 4 & 129 & \\
\hline \multirow{4}{*}{ Uploader } & News agency & 5 & 50 & 6 & 3 & 0 & 64 & \multirow{4}{*}{$<0.001$} \\
\hline & Individual users & 4 & 47 & 5 & 6 & 1 & 63 & \\
\hline & Religious personnel & 18 & 2 & 0 & 0 & 0 & 20 & \\
\hline & Healthcare professional & 0 & 0 & 2 & 4 & 3 & 9 & \\
\hline \multirow{2}{*}{ Attitude } & For & 25 & 1 & 0 & 0 & 0 & 26 & \multirow{2}{*}{$<0.001$} \\
\hline & Against & 2 & 98 & 13 & 13 & 4 & 129 & \\
\hline
\end{tabular}

The DISCERN scores were significantly higher in the videos presented by females compared to men ( $p \leq 0.001)$, in the videos uploaded by healthcare professionals compared to other sources ( $p \leq 0.001$ ), and in the videos against FGM compared to the videos defending FGM ( $p \leq 0.001)$ (Chi-square test)

Table 3. GQS scores

\begin{tabular}{lllllllll}
\hline \multirow{2}{*}{ Gender } & $\mathbf{1}$ & $\mathbf{2}$ & $\mathbf{3}$ & $\mathbf{4}$ & $\mathbf{5}$ & Total & $\mathbf{p}$ \\
& Male & 16 & 10 & 0 & 0 & 1 & 27 & $<0.001$ \\
& Female & 6 & 77 & 30 & 12 & 4 & 129 & \\
& News agency & 1 & 44 & 15 & 3 & 1 & 64 & \\
\multirow{3}{*}{ Uploader } & Individual users & 7 & 35 & 14 & 6 & 1 & 63 & $<0.001$ \\
& Religious personnel & 14 & 6 & 0 & 0 & 0 & 20 & \\
& Healthcare professional & 0 & 2 & 1 & 3 & 3 & 9 & \\
\hline \multirow{2}{*}{ Attitude } & For & 19 & 7 & 0 & 0 & 0 & 26 & $<0.001$ \\
& Against & 3 & 80 & 30 & 12 & 5 & 130 & \\
\hline
\end{tabular}

The GQS scores were significantly higher in the videos presented by females compared to men $(p \leq 0.001)$, in the videos uploaded by healthcare professionals compared to other sources $(p \leq 0.001)$, and in the videos against FGM compared to the videos defending FGM ( $p \leq 0.001)$ (Chi-square test) 


\section{DISCUSSION}

The physical and psychological effects of female genital mutilation have been demonstrated in the literature $(13,14)$. A study conducted in Mali and Burkina Faso showed that women with FGM had a lower sense of trust and a higher prevalence of psychological trauma and relationship problems. The study also indicated that these women had less pleasure from sex, reached orgasm relatively later, and also had a higher prevalence of complications such as urethral and anal rupture or urination problems due to urethral stricture, difficulty in sexual intercourse due to frequent urinary tract infections and vaginal narrowing, and painful sexual intercourse $(15,16)$. Despite the presence of many studies on FGM reporting on these complications, our study indicated that the number of videos uploaded by healthcare professionals was highly limited, which implicates that healthcare professionals do not pay enough attention to this issue. Nonetheless, the high quality and reliability scores of the videos uploaded by healthcare professionals show that these professionals have mastered the subject matter. Accordingly, we suggest that the awareness of healthcare professionals on this issue should be increased.

In our study, the videos were mostly uploaded by individual users and news agencies, which shows that women suffering from FGM share their grievances on YouTube and that the mass media is relatively more interested in the subject matter. Nevertheless, considering the insufficient quality and reliability of the videos analyzed in our study, it can be asserted that even the women suffering from FGM do not have enough information about the complications of FGM or do not care enough about this subject matter.

The influence of religion on society, particularly in African and Middle Eastern countries, is undeniable, and religious leaders' opinions are highly valued $(17,18)$. However, the FGM videos shared by religious personnel in our study were not only full of misinformation but also harmful because they promoted FGM, which provides an idea about the role of religious personnel in the widespread implementation of FGM in these countries.
In countries where FGM is commonly practiced, most men seem to dream of a female partner with FGM. One of the reasons for this is that the vagina narrowed by some FGM techniques is considered to provide the male partner greater pleasure during sexual intercourse, while another reason is the moral, cultural, and honor values attributed to FGM through the reduction of sexuality of women (19). In a study conducted in 13 countries in Africa, it was reported that women with FGM had a $40 \%$ higher chance of getting married (20). The relatively lower number of videos shared by men in our study and the lower quality and reliability of the videos implicate that men are not interested in and are less knowledgeable about this subject matter when compared to women.

In many countries, FGM is practiced even before girls reach puberty. Moreover, it is known that $90 \%$ of FGMs in Egypt are performed between the ages of $5-13$, with the intention of suppressing their sexual desires that emerge with the hormonal changes occurring during puberty. In addition, it has been reported that FGM is mostly performed in the first two months of life in Yemen and that the average age of FGM is gradually decreasing in countries such as Burkina Faso, Kenya, and Mali $(21,22)$. Children in this age range are under the control of their families and do not have an individual say, and thus it is not possible for them to take a stand against FGM. In our study, almost all the women who uploaded the videos were against FGM. Therefore, we suggest that even if FGM cannot be prevented, it should be delayed until the women gain their voice.

The limitation of our study was that it only included English-language videos and did not evaluate the videos produced in the local languages of Africa, where FGM is frequently applied. In addition to this limitation, the strength of our study is that the first study on this subject was conducted prospectively.

\section{CONCLUSION}

YouTube.com videos may be beneficial for the prevention of FGM, but more attention should be paid to this issue, particularly by healthcare professionals, and more reliable videos with the higher quality should be shared. However, it is necessary to be aware of the videos supporting FGM and take steps to prevent them. 


\section{Conflict of interest}

The authors declare to have no conflicts of interest.

\section{Financial Disclosure}

The authors declared that this study has received no financial support.

\section{Informed Consent}

Patient data did not use in the study.

\section{Ethical Approval}

In this study, ethical approval did not obtain because it did not use patient data. The study protocol conformed to the ethical guidelines of the Helsinki Declaration.

\section{Author Contributions}

$\mathrm{MD}$; conceptualized the project, designed the study questionnaire in its final form, analyzed the collected data, and wrote the entire manuscript. VA; helped in the data collection, did the statistical analysis of the collected data, and made sense of it. MD; helped in data collection, proofreading, revising, and drafting of tables \& figures of the final version of the manuscript. VA; helped in data collection, proofreading, revising the final version of the manuscript.

\section{REFERENCES}

1. Female Genital Mutilation/Cutting: A Statistical Overview and Exploration of the Dynamics of Change. United Nations Children's Fund, New York 2013;184-90.

2. World Health Organization. Female Genital Mutilation, Fact Sheet \#241. http://www.who.int/mediacentre/factsheets/fs241/en/ 2012.

3. Okeke TC, Anyaehie USB, Ezenyeaku CCK. An overview of female genital mutilation in Nigeria. Ann Med health Sci Res 2012;2(1):70-3.

4. Odoi AT. Female Genital Mutilation. Comprehensive Gynaecology in the Tropics (1st ed) Accra: Graphic Packaging Ltd 2005;268-78.

5. Sobel M. Female genital cutting in the news media: A content analysis. Int Commun Gazz 2015; 77(4): 384405.

6. Demir M, Taken K, Eryilmaz R, et al. YouTube as a Health Information Source: COVID-19 and Andrology. Med Bull of Haseki 2021; 59(2): 1-7.
7. Dhamayanti M. Digital Campaigns to Prevent Sexual Abuse in Early Childhood (Case study: Video Geni and Aksa in YouTube). Int J Multicl Multirelig Understanding 2019;6(10): 26-32.

8. Bernard A, Langille $M$, Hughes $S$, et al. A systematic review of patient inflammatory bowel disease information resources on the world wide web. Am J Gastroenterol 2007; 102(9):2070-7.

9. Charnock D, Shepperd S, Needham G, et al. DISCERN: an instrument for judging the quality of written consumer health information on treatment choices. J Epidemiol Commun H 1999;53:105-11.

10. Griffiths $\mathrm{KM}$, Christensen $\mathrm{H}$. Website quality indicators for consumers. J Med Internet Res 2005;7(55):1-13.

11. Griffiths KM, Christensen H. The quality and accessibility of Australian depression sites on the World Wide Web. Med J Australia 2002;176:97-104.

12. Singh AG, Singh S, Singh. YouTube romatoid artrit hakkında bilgi için - bir uyandırma çağrısı mı? J Rheumatol 2012;39 (5): 899-903.

13. Klein E, Helzner E, Shayowitz M, et al. Female genital mutilation: health consequences and complications-a short literature review. Obstet Gyn Int 2018;1-7.

14. Earp BD, Johnsdotter S. Current critiques of the WHO policy on female genital mutilation. Int $j$ Impot Res 2020;1-14. 9 .

15. Jones H, Diop N, Askew I, et al. Female genital cutting practices in Burkina Faso and Mali and their negative health outcomes. Stud Fam Plann 1999;30(3): 219-30.

16. Kandala NB, Ezejimofor MC, Uthman OA, et al. Secular trends in the prevalence of female genital mutilation/ cutting among girls: a systematic analysis. BMJ Glob Health 2018;3(5).

17. Agensky JC. Who governs? Religion and order in postcolonial Africa. Third World Q 2020;41(4):583-602.

18. Appau S, Mabefam MG. Prosperity for the poor: religion, poverty and development in Sub-Saharan Africa. In Moving from the Millennium to the sustainable development goals (pp. 243-265). Palgrave Macmillan, Singapore 2020;243-65.

19. Wagner N. Why female genital cutting persists. In Working Paper-International Economics Section. The Graduate Institute of Int and Development Studies, Erasmus Univ Rotterdam, Netherlands 2011. 
20. Bikhchandani S, Hirshleifer D, Welch I. Learning from the behavior of others: Conformity, fads, and informational cascades. J Econ Perspect 1998;12(3):151-70.

21. Shell-Duncan B, Herniund, Y. Are there "stages of change" in the practice of female genital cutting? Qualitative research finding from Senegal and the Gambia. Afr J Reprod Health 2006;10(2): 57-71.

22. US Department of Health and Human Services. Female Genital Cutting. http://www.womenshealth.gov/publications/our-publications/fact-sheet/female-genitalcutting.2009. 